\title{
THE LAST WETLANDS IN THE IER VALLEY NATURA 2000 PROTECTED AREA - CASE STUDY: THE HABITATS AROUND PIR VILLAGE, SATU MARE COUNTY, ROMANIA
}

\author{
Paul-Marian SZATMARI,2 \\ ${ }^{1}$ Biological Research Center, Botanical Garden "Vasile Fati" Jibou \\ 16 Wesselényi Miklós St., RO-455200 Jibou, Romania \\ ${ }^{2}$ Babeș-Bolyai University, 42 Republicii St., RO-400015 Cluj-Napoca, Romania \\ e-mail: paul_marian87s@yahoo.com
}

\begin{abstract}
In this paper are presented new scientific data from Ier Plain Natura 2000 protected area, located in the south-western part of Satu Mare County, north-western Romania. The fieldwork was carried out in the surroundings of Pir village, where we can still find natural and semi-natural habitats. Unfortunately, in the last few years these sites were heavily affected by human activity, and thus we recommend some urgent measures to stop and to prevent future damage. This area still preserves rare species of plants and animals, relicts from the colder periods and Natura 2000 protected habitats. All these ecosystems survived the great drainages that were carried out in the communist period. The study analyses the 10 Natura 2000 habitats identified in the area, habitats that shelters as many as 490 plant species. Each habitat is discussed separately, with mention of the rare and endangered species. During the fieldwork several relict plant species and associations were found. These are also presented in this paper. The results of this study are an addition to the data regarding the Ier Plain Natura 2000 protected site.

We also want to draw attention to the failure to follow the rules imposed by the European Union regarding the management of the Natura 2000 protected areas. For example, in the Ier Valley (Ier Plain) the destruction is still ongoing in the natural habitats.
\end{abstract}

Keywords: Ier Valley (Ier Plain), Natura 2000, threatened species, glacial relicts.

\section{Introduction}

Some decades ago, the plains in the north-western part of Romania were covered with forests, grasslands and huge wetlands that persisted here from the last glacial period [1]. The anthropogenic influences on these habitats started from the Stone Age, when the first settlements appeared [20]. The great forests were cleared only from the second part of the Middle Ages, but the vast majority of the ancient wetlands remained untouched until the communist period (in the 1960s), when almost all of the swamps were drained [1]. The former wetlands and extensive reedbeds were replaced by farmlands. A very few remains of the archaic vegetation are still preserved in some isolated places, but in recent years these too have been affected. The establishment of some Natura 2000 sites in the region starting in 2007 could not manage to stop the continuous degradation. The Ier Valley is probably one of the most affected sites in this region. Some places are still preserved in the vicinity of Pir village, where rare and endangered species have survived.

The area studied is situated in the northern part of the village, all those sites being part of the Natura 2000 Ier Valley protected area (Fig. 1). The territory is located between the Tășnad Hills in the south (where the village is located), the Ier Channel in the north, the dam and the 
county road 108M that connects the localities Tăşnad and Andrid in the east, and the village of Sălacea (Bihor County) in the west. The site is part of the Pannonian biogeographical region, the flora here being slightly different from the rest of the wetlands in the country. As a result of the direct contact with the hills in the south that have quite a different vegetation, we can find some uncharacteristic species for the lowlands, which makes this site even richer regarding the diversity of plant and animal species.

This valley overlaps ancient meanders in which the rivers Tisa, Someș and Crasna flowed at the beginning of the Holocene [20,1]. As a result, the fields here are alluvial type with swamp deposits [1]. In the northwestern part of the sector, slightly halophilic soils with a specific vegetation are encountered. On the contact with the hills there are some parts with reddish clay soils of Pleistocene age [11].

In the central part of the study area existed an island the local people named The Citadel (Vár; Cetate), where archaeologists have found a variety of objects from the Bronze Age dated back to the old Otomani culture [20]. The Citadel was surrounded by the waters of the Ier River, swamps and huge lakes that disappeared during the communist period.

The territory is intersected by a labyrinth of drainage channels and streams that arrive here from the hillsides, many areas being inaccessible especially in the rainy seasons. In very low-lying areas, the groundwater emerges to the surface.

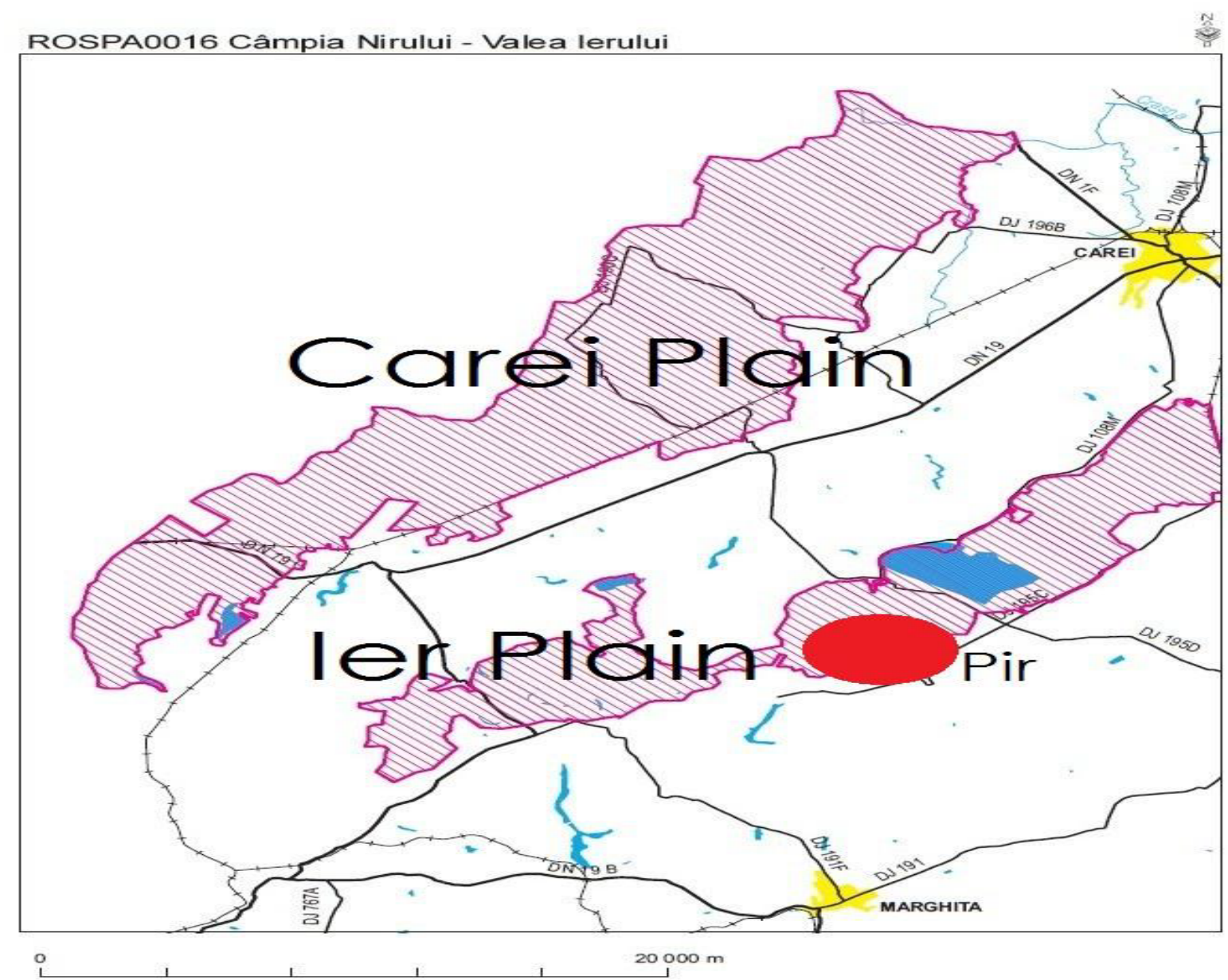

Fig. 1: The Natura 2000 sites Ier Plain and Carei Plain. The red dot represents the investigated area near Pir village.

The climate in this area is typical for the northern part of the Romanian Western Plain, 
colder and wetter than in the central and southern regions of the same plain [10]. Due to the surrounding hills, a local milder microclimate has been established. The higher banks and terraces with southern exposure are more exposed to solar radiation; consequently, the higher level of water evaporation generates different aspects to the vegetation. The remnants of the original alluvial forests and willows shelters species that require more humidity and a cooler climate. This is proven by the survival of some mountain species in the lowlands from the last ice age [10]. The remains of these swamps in the area of Pir village resemble those in the nearby Carei Plain (Vermeş Swamp from Sanislău and the wetlands at Resighea, Pişcolt, Curtuiuşeni). All these wetlands were connected in the past by a large network of surface waters. Due to excessive drainage, many of the rare and relict species did not survive, and even during the last two decades some of them became extinct.

In recent decades, a small amount of research regarding the flora around Pir village was carried out, notably by Carol Karácsonyi and Gavril Negrean, both considering the vegetation near the Piru Nou village a treasure in need of urgent protection (Fig. 3E \& 3F) [1]. Unfortunately, the local people did not take into account the scientific importance of the newly declared natural protected area, and the site was almost completly destroyed between 1980 and 1990. Other irreversible damage was done between 2010 and 2015, when a major part of the protected area was converted into arable land. As a result, in the last few years, some plant species such as Ophioglossum vulgatum, Eriophorum angustifolium, Thalictrum flavum, Triglochin palustris, Equisetum fluviatile, Erysimum cheiranthoides, Symphytum tanaicense or Alnus glutinosa have not been refound. Also, many birds that nested here have left this place. For example, the huge populations of grey heron (Ardea cinerea) and night heron (Nyctycorax nyctycorax) have vanished completely [1]. Nowadays the area is still rich in plant species, but with fewer populations each year.

\section{Materials and Methods}

The inventory of the species was carried out after frequent studies in the field in different seasons, between 2007 and 2017. To determine the species, different identification keys have been used [5, 3, 4, 17, 15]. The plants were collected and are being stored, in order to be deposited in an authorized herbarium.

For recognizing the plant associations and the present habitats, phytocenological survey has been used [16]. For the nomenclature of the habitats we used the Natura 2000 habitats guide in Romania [9, 6]. The National Red Lists used in the study are: Dihoru \& Negrean (2009) [7], Oltean et al., 1994 [14] and we also checked the National Red Lists from Hungary and the Carpathian Basin, because a part of the Ier Valley is situated on the country border $[12,13,21]$.

\section{Results and Discussion}

According to our researches, the territory studied is considered probably one of the richest in plant species. Until today, here were encountered around 500 species of plants, which is quite remarkable for such a small area $\left(11 \mathrm{~km}^{2}\right)$. The fact that these places were too swampy for agriculture made possible the survival of their habitats.

The whole plain in the northern part of the village is characterized by a mosaic of plant associations that indicate the richness encountered in the Ier Valley before the drainages. The dominant plant associations are: Caricetum acutiformis-ripariae Soó (1927) 1930, Caricetum 
gracilis Almquist 1929, Scirpo-Phragmitetum W. Koch 1926, Agrostidetum stoloniferae (Ujvárosi 1941) Burduja et al. 1956, Arrhenatheretum elatioris Br.-B1. ex Scherrer 1925, ScirpoCirsietum cani Bálátova-Tulácková 1973, Schoenoplectetum lacustris Chouchard 1928, Ranunculo repentis-Calthetum palustris Chifu et all. 2006, and Phalaridetum arundinaceae (Koch 1926) Libbert 1931. Other remarkable plant associations are Iretum pseudacori Eggler 1933, Peucedano officinalis-Asteretum sedifolii Soó 1947 corr. Borhidi 1996, and Artemisietum ponticae (Borza 1931 n.n.) Păun (1964) 1966. The former Piru Nou Protected Area still shelters a large variety of plant associations, of which the most important are: Scirpo-Phragmitetum W. Koch 1926, Caricetum gracilis Almquist 1929, Oenanthetum aquaticae Soó 1928, Calamagrostio-Salicetum cineraeae Soó et Zólyomi 1955, and Caricetum paniculatae Wangerin 1916, the last ones having a relict origin [10].

Along the watercourses are many more plant associations with: Typha angustifolia, $T$. latifolia, Carex disticha, Lycopus exaltatus, Eleocharis palustris, Typha laxmannii, Bolboschoenus maritimus. In the Ier Channel the dominant species on the river banks are Sagittaria sagittifolia, Sparganium erectum, Butomus umbellatus, Myosotis scorpioides etc. Elm (Ulmus minor) and oak (Quercus robur) trees, more than 80-100 years old, are the remnants of the ancient forests that covered the area. These species, along with Fraxinus angustifolia subsp. danubialis, suggest that the riparian forests were well established, being constantly submerged by the waters of the ancient rivers that flowed here. These forests are well known for their richness in plant and animal species.

\section{Relict species, habitats and plant associations}

In the former Piru Nou Natural Protected Area the riparian forests with willows and poplars have been reduced to a quarter of their initial extent, while the swamps and grasslands are almost extinct. With the disappearence of the springs, the relict species that survived here for millennia have not been found (Equisetum fluviatile, Ophioglossum vulgatum, Thelypteris palustris, Eriophorum angustifolium). Some remaining relict populations of Calamagrostis canescens and Carex paniculata still present are critically endangered (Fig.2A \& 2B). They form relict plant associations such as Calamagrostio-Salicetum cineraeae Soó et Zólyomi 1955, and Caricetum paniculatae Wangerin 1916.

The plant association Calamagrostio-Salicetum cineraeae Soó et Zólyomi 1955 forms a remarkable habitat, a remnant of colder times - thickets of grey willow (Salix cinerea) with the glacial relict Calamagrostis canescens (R4419). Small parts of this habitat survived in the area of the former reserve. This habitat does not have a correspondent in the Natura 2000 network.

Correspondent habitats for R4419 South-eastern Carpathian tickets of grey willow (Salix cinerea) with Calamagrostis canescens (Tufărișuri sud-est carpatice de zălog (Salix cinerea) cu Calamagrostis canescens):

NATURA 2000:-

EMERALD: 44. Temperate riverine and swamp forests and brush

CORINE: 44.921: Grey willow scrub

PAL.HAB 1999: 44.9213 Intra-Carpathian grey willow-carrs

EUNIS: F9.213 Intra-Carpathian grey willow-carrs

Plant associations: Calamagrostio - Salicetum cinereae Soó et Zólyomi 1934, Soó 1955 with subass. spiraeetosum salicifoliae Raţiu 1968. Synonym: Salix cinerea ass. Zólyomi 1931. 

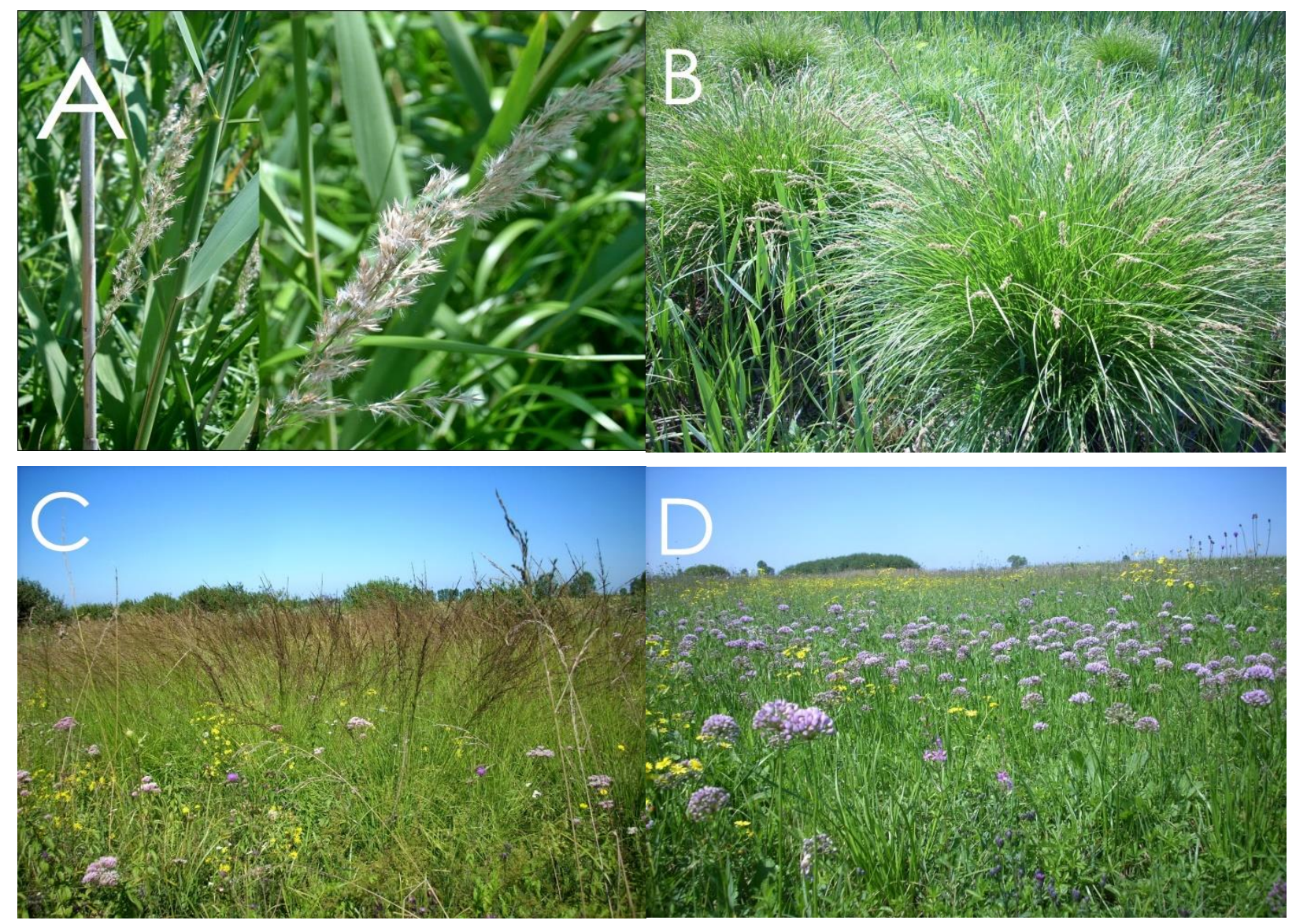

Fig. 2: A \& B Relict species. A. Calamagrostis canescens. B. Carex paniculata. C. Molinia caerulea habitat. D. Hygrophilous meadows with Allium angulosum.

The soils are slightly acidic with high humidity. The habitat is characteristic for the mountain valleys and depressions, mostly in the Eastern Carpathians, with very few sites in the Southern Carpathians and the northern part of the Apuseni Mountains [7]. In the lowlands of north-western Romania the habitat is also encountered in Nir (Carei) Plain, which is situated far from the nearest mountain region $[2,19]$. As a result, these habitats with the typical associations are most probably remnants from the colder periods, having a relict character. The normal altitude for this habitat is between 600-650 m, but in Ier Plain near Piru Nou it is found at $110 \mathrm{~m}$ a.s.1.

The woody vegetation is dominated by: Salix cinerea, Frangula alnus, Viburnum opulus. Other frequent species are: Populus tremula, Salix triandra, Salix fragilis. The herbaceous plants are represented by: Calamagrostis canescens, Scirpus sylvaticus, Poa trivialis, Deschampsia cespitosa, Molinia caerulea, etc. Glacial relict species encountered here are Calamagrostis canescens and Ribes nigrum (with an uncertain origin). Other relict species in the lowland at Piru Nou are Carex paniculata and Cirsium rivulare. Eriophorum angustifolium and Equisetum fluviatile have not been found in recent years and are probably extinct.

The conservation value for Romania of this habitat is high, due to the large number of rare and relict species [7]. 
Other associations with a relict character encountered in this area are: Caricetum paniculatae Wangerin 1916, Caricetum distichae Nowinski 1927, Caricetum vesicariae Chouard 1924, and Junco-Molinietum Preising 1951 ex Klapp 1954. These are typical of the hills and mountain regions. The populations of Molinia caerulea, Carex disticha and Carex paniculata confirm that the Ier Plain, along other regions in the north-western part of Romania, were possible glacial refugia and the species survived here because of the large swamps [10]. The association Cirsietum rivularis Nowinski 1926 corroborates the relict character of this vegetation, Cirsium rivulare being a species ecountered normally in the beech zone [5].

\section{Natura 2000 habitats}

A high number of habitats were found in the area, 10 of them being included in the Natura 2000 network. Four Natura 2000 habitats are new for the entire region of Ier Plain, missing from the description file of the site [22] (Table 1).

1530* Pannonic salt-steppes and salt-marshes (Pajişti şi mlaştini sărăturate panonice şi ponto-sarmatice)

Correspondent habitats in Romania encountered in the study area:

R1514 West-Pontic communities with Trifolium fragiferum, Cynodon dactylon and Ranunculus sardous (Comunități vest-pontice cu Trifolium fragiferum, Cynodon dactylon și Ranunculus sardous)

R1529 Ponto-Pannonic grasslands with Hordeum hystrix (Pajiști ponto-panonice de Hordeum hystrix)

R1530 Ponto-Pannonic grasslands with Festuca pseudovina, Peucedanum officinale and Artemisia santonicum subsp. patens (Pajiști ponto-panonice de Festuca pseudovina, Peucedanum officinale și Artemisia santonicum subsp. patens)

R1531 Ponto-Pannonic grasslands with Festuca pseudovina and Achillea collina (Pajiști ponto-panonice de Festuca pseudovina și Achillea collina)

R1532 Slightly halophilic Dacian communities with Aster sedifolius and Peucedanum officinale (Comunități dacice slab halofile cu Aster sedifolius și Peucedanum officinale)

The habitats are encountered mostly in the north-western part of the study area. The vegetation is quite remarkable, and probably unique in Satu Mare County. The plants are adapted to slightly halophilic soils, creating an island of vegetation completely different from the surroundings. The plant association Peucedano officinalis-Asteretum sedifolii Soó 1947 corr. Borhidi 1996, includes two rare species: Peucedanum officinale and Aster sedifolius. An interesting discovery is Peucedanum latifolium, a rarity in Romania, this location being the westernmost limit in the distribution area of the species. Component species: Eryngium planum, Serratula tinctoria, Centaurea pannonica, Carex distans, Seseli annuum, Viola hirta.

In other slightly halophilic habitats, with a high water level all year round, are encountered different species: Lythrum hyssopifolia, Potentilla supina, Chenopodium polyspermum, Atriplex oblongifolia, Puccinelia distans, Juncus gerardi, Carex vulpina, Carex otrubae, Juncus atratus, Ranunculus aquatilis, Ranunculus trichophyllus, Carex tomentosa, Carex panicea, Lythrum virgatum, Sanguisorba officinalis, etc. In the northern part of the former Piru Nou Natural Protected Area, the grasslands grade into plant associations growing on salty soils, with species such as: Trifolium fragiferum, Juncus bufonius, Hordeum geniculatum, Pulicaria vulgaris, Mentha pulegium, Schoenoplectus tabernaemontani. Other observations in 
Table 1.

Natura 2000 species: Cirsium brachycephalum (Fig.3G).

Species listed in the National Red Lists: Peucedanum officinale, Artemisia pontica, Lotus angustissimus, Senecio erucifolius, Iris spuria.

Other rare and interesting species: Clematis integrifolia, Erophila praecox, Scorzonera cana, Gagea pusilla, Gagea minima, Veronica orchidea, Colchicum autumnale, Asparagus officinalis, Carex caryophyllea, Sysimbrium officinale.

3130 Oligotrophic to mesotrophic standing waters with vegetation of the Littorelletea uniflorae and/or Isoëto-Nanojuncetea (Ape stătătoare oligotrofe până la mezotrofe, cu vegetaţie din Littorelletea uniflorae şi/sau Isoëto-Nanojuncetea)

Correspondent habitats in Romania encountered in the study area:

R2211 Danubian communities with Cyperus fuscus and Cyperus flavescens (Comunități danubiene cu Cyperus fuscus și C. flavescens)

These vanishing habitats are encountered mostly near the Ier River and other small watercourses. Component species: Eleocharis acicularis, Crypsis schoenoides, Veronica anagalloides, Potentilla supina, Atriplex prostrata, Bupleurum tenuissimum, Plantago uliginosa, Centaurium pulchellum, Rumex stenophyllus, Cyperus fuscus, Polygonum (Persicaria) hydropiper, Lythrum hyssopifolia, etc. Other observations in Table 1.

Natura 2000 species: -

Species listed in the National Red Lists: Taraxacum bessarabicum, Cirsium furiens, Veronica catenata.

Other rare and interesting species: Gnaphalium luteo-album.

3150 Natural eutrophic lakes with Magnopotamion or Hydrocharition-type vegetation (Lacuri eutrofe naturale cu vegetaţie de Magnopotamion sau Hydrocharition)

Correspondent habitats in Romania encountered in the study area:

R2202 Danubian communities with Lemna minor, L. trisulca, Spirodela polyrhiza and Wolffia arrhiza (Comunități danubiene cu Lemna minor, L. trisulca, Spirodela polyrhiza și Wolffia arrhiza)

R2203 Danubian communities with Salvinia natans, Marsilea quadrifolia, Azolla caroliniana and A. filiculoides - we didn`t manage to find it in the last 5 years, possible disappeared from the area (Comunități danubiene cu Salvinia natans, Marsilea quadrifolia, Azolla caroliniana și A. filiculoides)

R2205 Danubian communities with Hydrocharis morsus-ranae, Stratiotes aloides and Utricularia vulgaris (Comunități danubiene cu Hydrocharis morsus-ranae, Stratiotes aloides și Utricularia vulgaris)

R2206 Danubian communities with Potamogeton perfoliatus, P. gramineus, P. lucens, Elodea canadensis and Najas marina (Comunități danubiene cu Potamogeton perfoliatus, $P$. gramineus, P. lucens, Elodea canadensis și Najas marina)

Other observations in Table 1.

Natura 2000 species: -

Species listed in the National Red Lists: Salvinia natans, Utricularia vulgaris, Stratiotes aloides, Oenanthe aquatica, Typha laxmannii. 
Other rare and interesting species: Sparganium emersum.

3270 Rivers with muddy banks with Chenopodion rubri p.p. and Bidention p.p. vegetation (Râuri cu maluri nămoloase, cu vegetaţie din Chenopodion rubri p.p. şi Bidention p.p.)

Correspondent habitats in Romania encountered in the study area:

R5312 Ponto-Danubian communities with Bidens tripartita, Echinochloa crus-galli and Polygonum (Persicaria) hydropiper (Comunități ponto-danubiene cu Bidens tripartita, Echinochloa crus-galli și Polygonum hydropiper)

This habitat is encountered especially in the surrounding of waters with livestock. Other observations in Table 1.

Natura 2000 species: -

Species listed in the National Red Lists: Rorippa palustris.

Other rare and interesting species: Carex hordeistichos, Bidens cernua.

6410 Molinia meadows on calcareous, peaty or clayey-silt-laden soils (Molinion caeruleae) (Pajişti cu Molinia pe soluri carbonatice, turboase sau luto-argiloase) (Molinion caeruleae)

Correspondent habitats in Romania encountered in the study area:

R3710 Dacian grasslands with Molinia caerulea (Pajiști dacice cu Molinia caerulea)

This type of habitat occupies the edges of the wetlands where the water level is slowly dropping (Fig.2C). Due to anthropogenic impact, this type of habitat has suffered in recent years. Similar relict habitats are encountered in the neighboring Carei Plain Natural Protected Area [19]. Other observations in Table 1.

Natura 2000 species: -

Species listed in the National Red Lists: -

Other rare and interesting species: Euphorbia villosa, Odontites vernus, Molinia caerulea, Succisa pratensis, Poa palustris, Selinum carvifolia, Senecio erucifolius.

6430 Hydrophilous tall-herb fringe communities of plains and of the montane to alpine levels (Comunităţi de lizieră cu ierburi înalte higrofile de la câmpie şi din etajul montan până în cel alpin)

Correspondent habitats in Romania encountered in the study area:

R3708 Dacian-Getic communities with Angelica sylvestris, Crepis paludosa and Scirpus sylvaticus (Comunităţi daco-getice cu Angelica sylvestris, Crepis paludosa și Scirpus sylvaticus)

These communities are represented by tall hygrophilous herbs. Other observations in Table 1.

Natura 2000 species: Cirsium brachycephalum (Fig.3G).

Species listed in the National Red Lists: Leucanthemella serotina, Gentiana pneumonanthe, Oenanthe aquatica, Urtica kioviensis.

Other rare and interesting species: Sonchus palustris, Scrophularia scopolii, Inula helenium, Veronica spuria, Sium sisarum, Senecio paludosus, Ranunculus lingua, Geranium pratense, Geranium palustre, Galium rivale, Catabrosa aquatica, Epilobium obscurum, Carex paniculata, Festuca arundinacea, Filipendula ulmaria. 


\section{Alluvial meadows of river valleys of the Cnidion dubii (Pajişti aluviale ale văilor râurilor din Cnidion dubii)}

Correspondent habitats in Romania encountered in the study area:

R3712 Dacian communities with Deschampsia cespitosa and Agrostis stolonifera (Comunități dacice cu Deschampsia cespitosa și Agrostis stolonifera)

R3715 Danubian-Pannonic grasslands with Agrostis stolonifera (Pajiști danubianpanonice de Agrostis stolonifera)

R3716 Danubian-Pontic grasslands with Poa pratensis, Festuca pratensis and Alopecurus pratensis (Pajiști danubiano-pontice de Poa pratensis, Festuca pratensis și Alopecurus pratensis)

These habitats are among the richest in species and also the most threatened because of the uncontrolled ploughing. The vegetation in some parts is dominated by Cirsium brachycephalum, an endangered plant at European level, being a Natura 2000 priority species (Fig.3G). The dominant species are grasses such as: Deschampsia cespitosa, Agrostis stolonifera, Poa pratensis, Festuca pratensis, Festuca arundinacea and Alopecurus pratensis. Other component species: Carex elata, Carex vesicaria, Equisetum palustre, Thalictrum lucidum, Veronica scutellata, Rumex hydrolapathum, Melilotus altissimus, Euphorbia palustris, Euphorbia villosa, Selinum carvifolia, Sium latifolium, S. sisarum, Peucedanum carvifolia, Epilobium roseum, Cardamine pratensis subsp. matthiolii, Galium palustre subsp. elongatum, Galium rubioides, Succisa pratensis, Senecio erraticus, Pulicaria dysenterica, Melilotus dentatus, Briza media, Iris pseudacorus, Juncus articulatus, Carum carvi, Epilobium hirsutum, etc. Other observations in Table 1.

Natura 2000 species: Cirsium brachycephalum (Fig.3G).

Species listed in the National Red Lists: Veronica catenata, Anacamptis laxiflora subsp. elegans, Succisela inflexa, Stellaria palustris, Gentiana pneumonanthe, Ranunculus acris subsp. strigulosus, Carex disticha, Leucanthemella serotina, Iris spuria (Fig.3H).

Other rare and interesting species: Hieracium caespitosum, Juncus atratus, Lathyrus palustris, Ononis spinosiformis, Viola pumila, Viola stagnina, Eleocharis uniglumis, Achillea aspleniifolia, Taraxacum palustre, Allium angulosum (Fig.2D), Gratiola officinalis, Clematis integrifolia, Deschampsia cespitosa subsp. parviflora, Euphorbia lucida, Cirsium rivulare, Poa palustris, Galium boreale, Rorippa amphibia, Rhinanthus angustifolius, Rumex palustris, Veronica longifolia, Sonchus arvensis subsp. uliginosus, Sonchus palustris, Geranium palustre, Molinia caerulea, Deschampsia cespitosa, Selinum carvifolia, Sium latifolium, Euphorbia palustris, Plantago uliginosa, Succisa pratensis, Erysimum repandum, Senecio paludosus, Sium sisarum, etc.

6510 Lowland hay meadows (Alopecurus pratensis, Sanguisorba officinalis) Fânețe de joasă altitudine (Alopecurus pratensis, Sanguisorba officinalis)

Correspondent habitats in Romania encountered in the study area:

R3802 Dacian-Getic grasslands with Arrhenatherum elatius (Pajiști daco-getice de Arrhenatherum elatius)

The habitat is encountered mainly on the higher parts of the land, between swamps or usually on the edges. Many species from the neighbouring hills have found shelter in this habitat: 
Primula veris, Pulmonaria mollis, Peucedanum cervaria, Polygala comosa, Viola hirta, Gagea minima, G. villosa, Ornithogallum boucheanum, O. ortophyllum subsp. kochii, Hieracium lachenalii, Filipendula vulgaris, Salvia pratensis, Trifolium montanum, Seseli annuum, Achillea collina, A. setacea. These species and others such as: Carex tomentosa, Peucedanum alsaticum, Asparagus officinalis, Dianthus carthusianorum, Euphorbia salicifolia, Potentilla leucopolitana, Nepeta nuda, Silene vulgaris are growing on the site of the former island surrounded by waters. Other observations in Table 1.

Natura 2000 species: -

Species listed in the National Red Lists: Rhinanthus borbasii, Seseli pallasii, Saxifraga bulbifera, Anacamptis morio, Dianthus giganteiformis subsp. pontederae.

Other rare and interesting species: Clematis integrifolia, Inula salicina subsp. aspera, Picris hieracioides subsp. spinulosa, Plantago altissima, Malva pusilla, Lolium temulentum, Hesperis sylvestris, Fumaria parviflora, Dasypyrum villosum, Camelina sativa, Brassica nigra, Aegylops cylindrica.

At the direct contact with the hills, xerophilous vegetation is encountered, with species such as: Chrysopogon gryllus, Seseli pallasii, Astragalus cicer, Nonea pulla, Lappula squarrosa, Leopoldia comosa, Campanula glomerata, Onobrychis arenaria, Veronica austriaca, Vicia pisiformis, Potentilla chrysantha, Trifolium rubens, Thalictrum minus, Genista tinctoria, Echinops sphaerocephalus, Reseda luteola, Nigella arvensis, etc.

91E0* Alluvial forests with Alnus glutinosa and Fraxinus excelsior (Alno-Padion, Alnion incanae, Salicion albae) [Păduri aluviale de Alnus glutinosa şi Fraxinus excelsior (Alno-Padion, Alnion incanae, Salicion albae)]

Correspondent habitats in Romania encountered in the study area:

R4407 Danubian forests with white willow (Salix alba) and Rubus caesius (Păduri danubiene de salcie albă (Salix alba) cu Rubus caesius)

Many of these alluvial forest types were cleared or burned. At the present day only some islands or galleries along the channels have survived, for example in the former Piru Nou Natural Protected Area. Some of the dominant species in addition to Salix alba and Rubus caesius are: Salix fragilis, S. cinerea, S. viminalis, S. triandra, S. caprea, Cornus sanguinea, Sambucus nigra, Ulmus minor, Crataegus monogyna, Rosa canina, Rubus praecox and Prunus spinosa. The most common herbaceous species are: Urtica dioica, Valeriana officinalis, Myosoton aquaticum, Carex acutiformis, Angelica sylvestris, Eupatorium cannabinum, Galium aparine, Torilis japonica, Lycopus europaeus, Lythrum salicaria, Thalictrum lucidum, Caltha palustris, Scirpus sylvaticus, Epilobium hirsutum, Iris pseudacorus. Other observations in Table 1.

Natura 2000 species: -

Species listed in the National Red Lists: -

Other rare and interesting species: Galium rivale, Salix purpurea, S. purpurea subsp. lambertiana, S. caprea, Silene baccifera.

92A0 Salix alba and Populus alba galleries (Păduri-galerii (zăvoaie) de Salix alba şi Populus alba)

Correspondent habitats in Romania encountered in the study area:

RR4406 Danubian-Pannonic forests with white poplar (Populus alba) and Rubus caesius 
(Păduri danubian-panonice de plop alb (Populus alba) cu Rubus caesius)
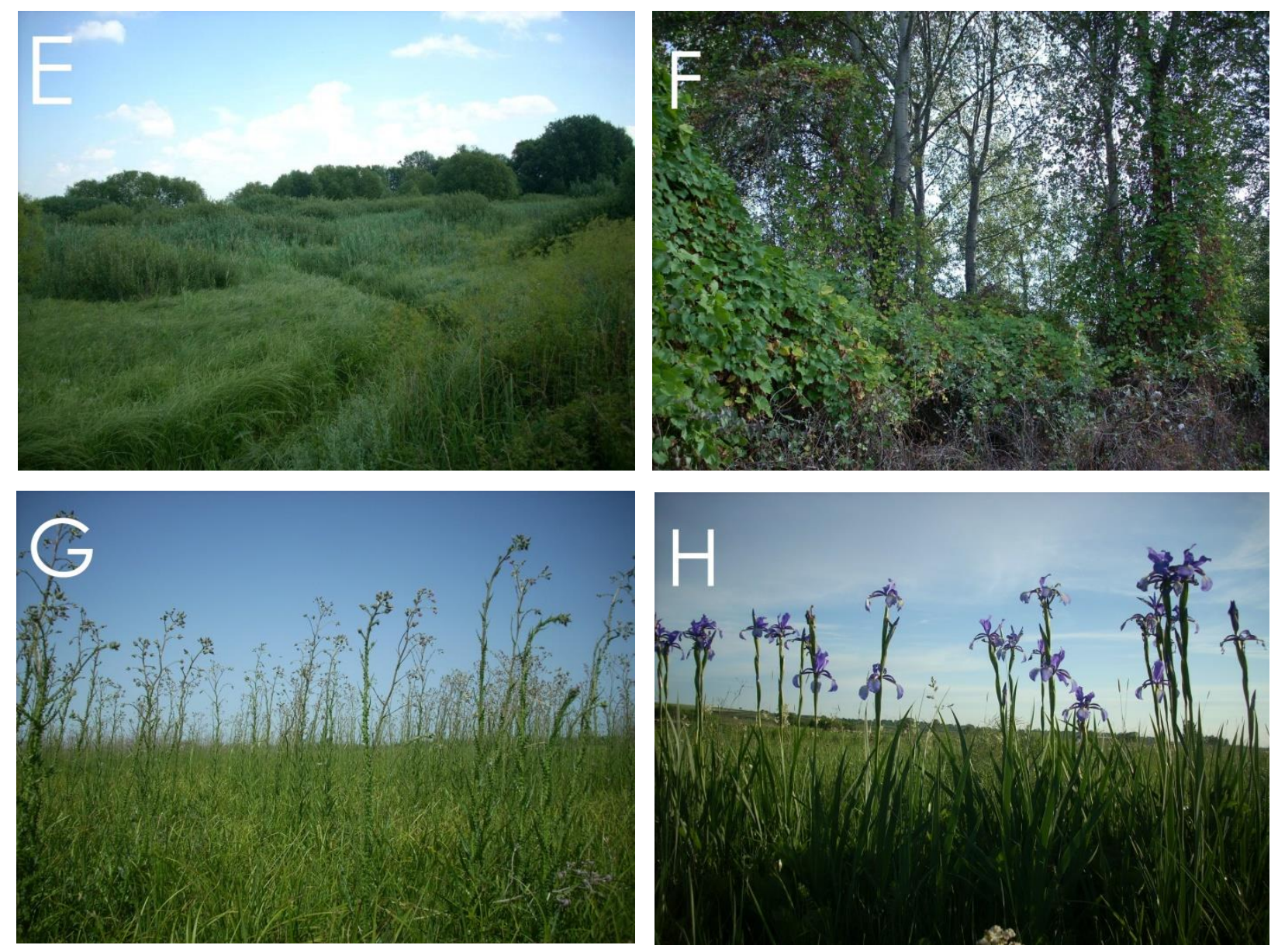

Fig. 3: E \& F - Aspects of the former Piru Nou Natural Protected Area. G \& H - meadows with protected species before the 2015/2016 ploughing: Cirsium brachycephalum (G), Iris spuria (H). Now these habitats are transformed into corn (maize) fields.

The most important remnants of this habitat are encountered in the former Piru Nou Natural Protected Area. The dominant trees are white poplar (Populus alba) and different species of willow (Salix alba, S. fragilis, S. cinerea, S. triandra). Other frequent species are: Populus tremula (rarely encountered in the plains), P. nigra, Viburnum opulus, Frangula alnus, Rhamnus cathartica, Cornus sanguinea, Euonymus europaeus, Sambucus nigra, Ulmus minor, etc., with various climbing species such as: Vitis vulpina, Humulus lupulus, H. scandens, Echinocystis lobata, Calystegia sepium, Solanum dulcamara, etc. Ribes nigrum and R. rubrum of uncertain origin are also growing in this habitat. These forest-galleries are located around a huge drained swamp, which is now occupied by impenetrable reeds, a real sanctuary for wildlife. Other observations in Table 1.

Natura 2000 species: -

Species listed in the National Red Lists: Ribes nigrum, Oenanthe aquatica, Thelypteris palustris.

Other rare and interesting species: Geranium palustre, Lathyrus palustris, Salix purpurea subsp. lambertiana, Vitis vulpina, Galium rubioides. 
Table 1: Natura 2000 habitats from Ier Valley located in the northern part of Pir village. Annex 2: Types of natural habitats whose conservation requires the declaration of special areas of conservation (OUG 57/2007 [22])

\begin{tabular}{|c|c|c|}
\hline Habitat type & $\begin{array}{l}\text { Plant associations from the } \\
\text { studied area }\end{array}$ & Observations \\
\hline $\begin{array}{l}\text { 1530* Pannonic salt-steppes } \\
\text { and salt-marshes }\end{array}$ & $\begin{array}{l}\text { * Trifolio fragiferi-Cynodontetum } \\
\text { Br.- Bl. et Balas } 1958 \\
\text { * Peucedano officinalis-Asteretum } \\
\text { sedifolii Soó } 1947 \\
\text { corr. Borhidi } 1996 \text { (syn. Peucedano } \\
\text { officinalis-Festucetum pseudovinae } \\
\text { (Rapaics 1927) Pop 1968) } \\
\text { * Achilleo - Festucetum pseudovinae } \\
\text { Soó (1933) corr. Borhidi 1996 } \\
\text { * Puccinellietum distantis Soó } 1937 \\
\text { * Heleochloetum schoenoidis (Soó } \\
\text { 1933) Țopa } 1939 \text { em. I.Pop } 1968\end{array}$ & $\begin{array}{l}\text { Priority habitat according to Annex } 1 \\
\text { Habitats Directive } 92 / 43 / \text { EEC. } \\
\text { - The only location in Western Romania } \\
\text { where the rare species Peucedanum } \\
\text { latifolium grows; this is also the } \\
\text { westernmost limit of the area of this } \\
\text { species in Central Europe. }\end{array}$ \\
\hline $\begin{array}{l}\text { 3130 Oligotrophic to } \\
\text { mesotrophic standing waters } \\
\text { with vegetation of the } \\
\text { Littorelletea uniflorae and/ or } \\
\text { Isoëto-Nanojuncetea }\end{array}$ & $\begin{array}{l}\text { * Juncetum bufonii Felföldy } \\
1942 \\
* \text { Cypero - Limoselletum Kornek } \\
1960\end{array}$ & $\begin{array}{l}\text { - The livestock are slowly destroying } \\
\text { these fragile habitats. } \\
\text { - The species Limosella aquatica is } \\
\text { missing, but Cyperus fuscus cover whole } \\
\text { areas of former lakes. }\end{array}$ \\
\hline $\begin{array}{l}3150 \text { Natural eutrophic lakes } \\
\text { with Magnopotamion or } \\
\text { Hydrocharition-type } \\
\text { vegetation }\end{array}$ & $\begin{array}{l}\text { * Lemnetum minoris Soó } 1927 \\
* \text { Lemnetum trisulcae Knapp et } \\
\text { Stoffers } 1962 \\
\text { * Lemno-Spirodeletum Koch } 1954 \\
* \text { Hydrocharitetum morsus-ranae } \\
\text { van Langendonck } 1935 \text { (syn. } \\
\text { Stratiotetum aloidis Nowinski } 1930 \\
\text { subass. hydrocharietosum Soó 1964) } \\
* \quad \text { Lemno-Utricularietum vulgaris } \\
\text { Soó (1928) } 1947 \\
* \text { Potamo-Ceratophylletum submersi } \\
\text { Pop } 1962 \\
* \text { Lemno-Hydrocharitetum morsus- } \\
\text { ranae (Oberd.) Passarge } 1978 \\
* \quad \text { Potamogetonetum nodosi (Soó } \\
\text { 1960) Segal 1964 } \\
* \text { Ceratophylletum demersii Hild } \\
\text { 1956 }\end{array}$ & $\begin{array}{l}\text { - Stratiotes aloides is very rare in these } \\
\text { habitats, so that Hydrocharis morsus- } \\
\text { ranae covers almost the entire water } \\
\text { surface; also, Lemna trisulca create } \\
\text { another facies in this association, } \\
\text { mentioned for the northwestern part of } \\
\text { Romania [16]. }\end{array}$ \\
\hline $\begin{array}{l}\text { 3270 Rivers with muddy } \\
\text { banks with Chenopodion rubri } \\
\text { p.p. and Bidention p.p. } \\
\text { vegetation }\end{array}$ & $\begin{array}{l}\text { * Bidenti - Polygonetum } \\
\text { hydropiperis Lohm. in Tüxen } 1950 \\
* \quad \text { Xanthio strumarii -Bidentetum } \\
\text { tripartitae Timár 1947 } \\
* \quad \text { Echinochloo-Polygonetum } \\
\text { lapathifolii Soó et Csürös } 1974\end{array}$ & $\begin{array}{l}\text { This habitat is affected by the livestock } \\
\text { that uses these watersources. }\end{array}$ \\
\hline $\begin{array}{l}\text { 6410 Molinia meadows on } \\
\text { calcareous, peaty or clayey- } \\
\text { silt-laden soils (Molinion } \\
\text { caeruleae) }\end{array}$ & $\begin{array}{l}\text { * Junco-Molinietum Preising } 1951 \\
\text { ex Klapp } 1954\end{array}$ & $\begin{array}{l}\text { There are some differences between the } \\
\text { habitats regarding the altitude; those from } \\
\text { the lowlands are poorer in species, but } \\
\text { very important for their relict character. } \\
\text { !!! The habitat is missing from the Natura } \\
2000 \text { Ier Plain description file. }\end{array}$ \\
\hline $\begin{array}{l}\text { 6430 Hydrophilous tall-herb } \\
\text { fringe communities of plains } \\
\text { and of the montane to alpine } \\
\text { levels }\end{array}$ & $\begin{array}{l}\text { * Scirpetum sylvatici Ralski } 1931 \\
\text { em. Schwich } 1944 \\
* \text { Angelico sylvetris-Cirsietum cani } \\
\text { Burescu } 1998 \\
\text { * Cirsietum rivularis Nowinski } 1926\end{array}$ & $\begin{array}{l}\text { - It has also a relict character in the } \\
\text { lowlands. } \\
\text { - The association is very important } \\
\text { because of the species Cirsium rivulare, } \\
\text { which is encountered normally in the } \\
\text { mountain region. }\end{array}$ \\
\hline
\end{tabular}




\begin{tabular}{|c|c|c|}
\hline $\begin{array}{l}\text { 6440 Alluvial meadows of } \\
\text { river valleys of the Cnidion } \\
\text { dubii }\end{array}$ & $\begin{array}{l}\text { * Poëtum pratensis Răvăruţ et al. } \\
1956 \\
\text { * Ranunculo repentis-Alopecuretum } \\
\text { pratensis Ellmauer } 1933 \\
* \text { Agrostidetum stoloniferae } \\
\text { (Ujvárosi 1941) Burduja et al. } 1956 \\
\text { * Agrostio- } \\
\text { Deschampsietum } \\
\text { Ujvárosi } 1947 \\
\text { * Cirsio cani-Festucetum pratensis } \\
\text { Májovsky ex Ruzicková } 1975\end{array}$ & $\begin{array}{l}\text { - Contains many interesting species, } \\
\text { usually encountered in the higher } \\
\text { altitudes. } \\
\text { !!! The habitat is missing from the Natura } \\
2000 \text { Ier Plain description file. }\end{array}$ \\
\hline $\begin{array}{l}\text { 6510 Lowland hay meadows } \\
\text { (Alopecurus pratensis, } \\
\text { Sanguisorba officinalis) }\end{array}$ & $\begin{array}{l}\text { * Arrhenatheretum elatioris Br.-Bl. } \\
\text { ex Scherrer } 1925\end{array}$ & $\begin{array}{l}\text { !!! The habitat is missing from the Natura } \\
2000 \text { Ier Plain description file. }\end{array}$ \\
\hline $\begin{array}{l}\text { 91E0* Alluvial forests with } \\
\text { Alnus glutinosa and Fraxinus } \\
\text { excelsior (Alno-Padion, } \\
\text { Alnion incanae, Salicion } \\
\text { albae) }\end{array}$ & $\begin{array}{l}\text { * Salicetum albae Issler } 1924 \\
\text { * Salicetum fragilis } \\
\text { Passarge } 1957\end{array}$ & $\begin{array}{l}\text { Priority habitat according to Annex } 1 \\
\text { Habitats Directive } 92 / 43 / \text { EEC. } \\
\text { - Unfortunately, the alluvial forests with } \\
\text { Salix alba and Salix fragilis, were } \\
\text { destroyed. One of the remaining habitats } \\
\text { is found at Piru Nou, attesting the archaic } \\
\text { vegetation. } \\
\text { !!! The habitat is missing from the Natura } \\
2000 \text { Ier Plain description file. }\end{array}$ \\
\hline $\begin{array}{l}\text { 92A0 Salix alba and Populus } \\
\text { alba galleries }\end{array}$ & $\begin{array}{l}\text { * Salici-Populetum Meijer-Drees } \\
1936\end{array}$ & $\begin{array}{l}\text { - Besides the Salix alba forest, the } \\
\text { remaining habitat at Piru Nou, mentioned } \\
\text { above, still conserve another important } \\
\text { habitat (with Populus alba). }\end{array}$ \\
\hline
\end{tabular}

\section{Conclusions}

After years of fieldwork (2007-2017), an impressive database comprising almost 500 species was created, especially regarding the flora of the studied territory. Many species are new for Satu Mare County [18], others are rare and endangered at a European level. Due to the presence of some Natura 2000 habitas, it would be advisable to keep human activities in this area to a minimum level, for example the practicing of rational mowing. Four of the ten observed Natura 2000 habitats are new for the entire Ier Plain.

All these species and habitats indicate that the surrounding sites near Pir village still preserve many important ecosystems that need protection. The high number of habitats and plant species, which represent three quarters of all species encountered in Ier Valley, are strong enough evidence to support the establishment of a strictly protected area in the region. Also, this part of the Ier Plain could be the most eligible to propose an ecological reconstruction in the area.

With this paper we also want to draw to the attention of the general public that these habitats are being destroyed year by year (by plowing, vegetation burning, overgrazing, drainage, deforestation), even though they are protected and are situated within the perimeter of the Natura 2000 Protected Area of Ier Plain.

\section{REFERENCES}

1. Ardelean, G., Karácsonyi, K., 2002, Flora şi fauna Văii Ierului (înainte şi după asanare), Editura Bion, Satu Mare.

2. Ardelean, G., Karácsonyi, K., 2005, Flora, vegetaţia, fauna şi ecologia nisipurilor din nord-vestul României, Editura Daya, Satu Mare. 
3. Beldie, Al., 1977, Flora României - Determinator ilustrat al plantelor vasculare. Vol. I. Editura Academiei Republicii Socialiste România, Bucureşti.

4. Beldie, Al., 1979, Flora României - Determinator ilustrat al plantelor vasculare. Vol. II. Editura Academiei Republicii Socialiste România, Bucureşti.

5. Ciocârlan, V., 2009, Flora ilustrată a României, Editura Ceres, Bucureşti.

6. Combroux, I., Thiry, E., Ţoia, T., 2007, Caiet de habitate şi specii - Fişe pilot, Editura Balcanic, Timişoara.

7. Dihoru, G., Negrean, G., 2009, Cartea Roşie a plantelor vasculare din România, Editura Academiei Române, Bucureşti.

8. Doniţă, N., Popescu, A., Păucă-Comănescu, M., Mihăilescu, S., Biriş, I.-A., 2005, Habitatele din România, Editura Tehnică - Silvică, București.

9. Gafta, D., Mountford, J. O., 2008, Manual de interpretare a habitatelor Natura 2000 din România. Ministerul Mediului şi Dezvoltării Durabile, Cluj-Napoca.

10. Karácsonyi, C., 1987, Elementele florei montane în staţiuni de joasă altitudine din nord-vestul României. Studii şi Cercetări Biologice, Seria Biologie Vegetală, 39 (2): 101-107.

11. Karácsonyi, K., 2009-2010, Flora Dealurilor Tăşnadului şi a colinelor marginale, Muzeul Judetean Satu Mare, Studii şi Comunicări, Seria Știinţele Naturale şi Medicale. 10-11: 41-89.

12. Király, G., 2007, Vörös Lista. A Magyarországi edényes flóra veszélyeztetett fajai. Red list of the vascular flora of Hungary, Lővér Print, Sopron.

13. Németh, F., 1989, Száras növények. [Vascular plants]. In: Rakonczay Z. (ed.): Vörös Könyv. A Magyarországon kipusztult és veszélyeztetett állat- és növényfajok. [Red Data Book. Extinct and threatened animal and plant species of Hungary]. Akadémiai Kiadó, Budapest, pp. 265-325.

14. Oltean, M., Negrean, G., Popescu, A., Roman, N., Dihoru, G., Sanda, V., Mihăilescu, S., 1994, Lista Roşie a plantelor superioare din România, Studii, sinteze, documentaţii de ecologie, Academia Română, 1: 1-52.

15. Roskov, Y., Abucay, L., Orrell, T., Nicolson, D., Bailly, N., Kirk, P.M., Bourgoin, T., DeWalt, R.E., Decock, W., De Wever, A., Nieukerken, E. van, Zarucchi, J., Penev, L., eds. (2017), Species 2000 \& ITIS Catalogue of Life, 28th November 2017. Digital resource at www.catalogueoflife.org/col. Species 2000: Naturalis, Leiden, the Netherlands.

16. Sanda, V., Öllerer, K., Burescu, P., 2008, Fitocenozele din România, Editura Ars Docendi, Universitatea din Bucureşti, Bucureşti.

17. Sârbu, I., Ştefan, N., Oprea, A., 2013, Plante vasculare din România: determinator ilustrat de teren, Editura VictorBVictor, Bucureşti.

18. Szatmari, P.-M., 2011, Adăugiri la flora judeţului Satu Mare, Muzeul Judeţean Satu Mare, Studii şi Comunicări, Seria Știinţele Naturale şi Medicale, 12: 55-64.

19. Szatmari, P.-M., 2015, Additional glacial relicts in Carei Plain natural protected area, north-western Romania, Acta Horti Botanici Bucurestiensis, 42 (1): 23-40.

20. Uszkai, Á., Bokor, I., 2000. Szilágypér község kismonográfiája. Editura Europrint, Satu Mare.

21. Witkowski, Z. J., Król, W., Solarz, W., Kukuła, K., Okarma, H., Pawłowski, J., Perzanowski, K., Ruzicka, T., Sandor, J., Stanova, V., Tasenkevich, L., Vlasin, M., 2003, Carpathian List of Endangered Species, WWF and Institute of Nature Conservation, Polish Academy of Sciences, Vienna-Krakow.

22. *** Ordonanţa de urgenţă $\mathrm{nr} .57$ din 20 iunie 2007 privind regimul ariilor naturale protejate, conservarea habitatelor naturale, a florei şi faunei sălbatice. Guvernul României.

\section{ULTIMELE ZONE UMEDE DIN ARIA PROTEJATĂ NATURA 2000 VALEA IERULUI - STUDIU DE CAZ: HABITATELE DIN JURUL COMUNEI PIR, JUDEȚUL SATU MARE, ROMÂNIA}

\section{(Rezumat)}

În lucrarea de față sunt prezentate noi date științifice din situl Natura 2000 Valea Ierului, situat în sud-vestul județului Satu Mare, nord-vestul României. Cercetarea pe teren a fost efectuată în împrejurimile comunei Pir, unde se găsesc încă habitate umede naturale și seminaturale. Din păcate, în ultimii ani, aceste stațiuni au fost puternic afectate de activitatea umană, așadar se recomandă inițierea unor măsuri urgente de stopare și de prevenire a 
viitoarelor distrugeri. Această zonă păstrează în continuare specii rare de plante și animale, relicte din perioadele mai reci și habitate protejate Natura 2000. Toate aceste ecosisteme au supraviețuit marilor desecări făcute în perioada comunistă.

Studiul analizează cele 10 habitate Natura 2000 identificate în zonă, habitate care adăpostesc 490 de specii de plante. Discuțiile se axează asupra fiecărui habitat, cu menționarea speciilor rare și pe cale de dispariție. În timpul lucrărilor pe teren au fost identificate și specii de plante sau asociații vegetale cu caracter relictar, acestea fiind prezentate mai amănunțit în lucrare. Rezultatele acestui studiu sunt o completare a datelor privind situl Natura 2000 Câmpia Ierului.

De asemenea, se dorește atragerea atenției asupra nerespectării regulilor impuse de Uniunea Europeană în ceea ce privește regimul ariilor protejate Natura 2000. Spre exemplu, în Valea Ierului (Câmpia Ierului), distrugerile sunt încă în curs de desfăşurare în habitatele naturale. 